\title{
Empowering critical thinking skills by implementing scientific approach-based models among various students' ethnics
}

\author{
Didimus Tanah Boleng a,1,", Elsje Theodora Maasawet a,2, Krishna Purnawan Candra b,c,3 \\ a Department of Biology Education, Faculty of Teacher Training and Education, Mulawarman University, Jl. Muara Pahu, Kampus \\ Gunung Kelua, Samarinda 75119, Indonesia \\ ${ }^{b}$ Department of Agricultural Poduct Technology, Faculty of Agriculture, Mulawarman University, Jl. Pasir Balengkong, Kampus \\ Gunung Kelua, Samarinda 75119, Indonesia \\ c Doctoral Study Program of Environmental Science, Postgraduate Program, Mulawarman University, Jl. Sambaliung, Kampus Gunung \\ Kelua, Samarinda 75119 , Indonesia \\ ${ }^{1}$ didimus.tanahboleng@yahoo.com*; ${ }^{2}$ emaasawet@gmail.com; ${ }^{3}$ candra@faperta.unmul.ac.id \\ ${ }^{*}$ Corresponding author
}

\begin{tabular}{|c|c|}
\hline ARTICLE INFO & ABSTRACT \\
\hline \multirow[t]{2}{*}{$\begin{array}{l}\text { Article history } \\
\text { Received April 11, } 2020 \\
\text { Revised June 04, } 2020 \\
\text { Accepted June 15, } 2020 \\
\text { Published July 21, } 2020 \\
\text { Keywords } \\
\text { Guided inquiry } \\
\text { Problem-based learning } \\
\text { Scientific approach-based models } \\
\text { Students' ethnic }\end{array}$} & $\begin{array}{l}\text { In empowering students' } 21 \text { st century skills, the implementation of scientific approach- } \\
\text { based models (SAbM) is recommended. This quasi-experimental research was } \\
\text { conducted in senior high school in which the students were comprised of different } \\
\text { ethnics. The aim of the study was to determine the effect of SAbM on empowering } \\
\text { students' critical thinking skills (CTS). The SAbM implemented were Problem-Based } \\
\text { Learning (PBL), Guided Inquiry (GI), and PBL+GI combination. Furthermore, the } \\
\text { students' ethnics included were Javanese, Bugis, Kutai, Banjar, and Toraja. The } \\
\text { purposive sampling was used to determine the classes employed (i.e. 11th classes from } \\
\text { two senior high schools in Samarinda). The instrument used to collect CTS data was } \\
\text { questions test. The data were analyzed using two-way ANCOVA. The results showed } \\
\text { that there was no significant interaction between ethnic and learning models on the } \\
\text { students' CTS ( } p=0.219 \text { ), as also shown by the main effect of ethnic types }(p=0.583) \text {. } \\
\text { In contrast, there was a significant effect of SAbM on students' CTS }(p=0.0005) \\
\text { Through this study, SAbM need to be implemented continuously as it can optimize the } \\
\text { empowerment of students' } 21 \text { st Century skills. }\end{array}$ \\
\hline & $\begin{array}{l}\text { Copyright } \odot 2020 \text {, Boleng et al } \\
\text { This is an open access article under the CC-BY-SA license }\end{array}$ \\
\hline $\begin{array}{l}\text { approach-basec } \\
\text { doi: https://doi.o }\end{array}$ & $\begin{array}{l}\text { E. T., \& Candra, K. P. (2020). Empowering critical thinking skills by implementing scientific } \\
\text { among various students' ethnics. JPBI (Jurnal Pendidikan Biologi Indonesia), 6(2), 199-208. } \\
\text { 19/jpbi.v6i2.11845 }\end{array}$ \\
\hline
\end{tabular}

\section{INTRODUCTION}

Biology is a difficult subject for most high school students (Etobro \& Fabinu, 2017). Various topics and concepts in this subject have a high level of difficulty (Çimer, 2012). One of the difficult topics to study is "Cells and tissue organisms' body" topic. The cell is the smallest unit of the living body. Its microscopic size makes it difficult for students to imagine and to learn this topic. One of the main skills to make it easier for them to learn 
abstract topic is critical thinking skills (CTS) (Crowley, 2015). A scientific approach-based learning model (SAbM) seems to be appropriate to implement in such learning conditions.

The choice of learning models is adjusted or tailored to the learning objectives to be achieved by students (Tyabaev, Sedelnikova, \& Voytovich, 2015). Problem-Based Learning (PBL) and Guided Inquiry (GI) are two examples of scientific approach-based learning models usually used in biology. These learning models allow students to gain experience in problem formulating, data collecting, data analysis, discussing the results, making conclusions, and predicting (Firman, Baedhowi, \& Murtini, 2018).

In PBL activity, a real problem is faced at the beginning of learning activity then the students solve the problem by the teachers' guidance. However, the teachers do not dominate the learning activity (ServantMiklos, 2019) to improve students' critical thinking skills and make the best decision (Dring, 2019). During PBL implementation, students are involved collaboratively in their groups to carry out problem-solving activities (Andersen, Brunoe, \& Nielsen, 2019; Panlumlers \& Wannapiroon, 2015). In these activities, students are formulating the problem, planning the problem-solving process, implementing the problem-solving plan, and reflecting their learning (Panlumlers \& Wannapiroon, 2015). On the other hand, in GI, students will learn science concepts through the scientific process, from formulating problems to presenting findings (Arslan, 2014; Vlassi \& Karaliota, 2013). GI offers an integrated unit of inquiry, planned, and guided by an instructional team of a school librarian and teachers, allowing students to gain deeper understandings of the subject's area of curriculum content and information literacy concepts.

Unfortunately, the learning activity in biology subject at the $11^{\text {th }}$ class of Senior High School in Samarinda was still dominated by conventional learning (Boleng \& Maasawet, 2018). In line with those condition, the skills level of the students in analyzing, making conclusions, and predicting, in the learning in the cell and tissue of organisms' body subject at Senior High School, was low. Students are less interested in asking questions, doing analysis, lacking data to make conclusions, and less skilled in predicting based on the data. A study conducted by students is still lacking in sharpness, lack of focus, and lack of data (Boleng, Lumowa, Palenewen, \& Corebima, 2017). Therefore, the implementation of SAbM in biology subject in Samarinda is need to be carried out.

However, apart from choosing a learning model, there are other factors that also need to be considered to optimize student learning achievements. Students' ethnicity is believed can influences students' learning processes and outcomes. Different ethnics students bring out different attitudes and characters (Ahmad \& Yusof, 2010; Jayapalan, Wong, \& Aghamohammadi, 2018). The unique character of students tends to influence the learning process and the success of learning outcomes achievement, e.g., understanding concepts, critical thinking skills, creative thinking skills, social attitudes, and others. East Kalimantan is a region, which has multiethnic, socio-cultural, and religious diversity (Murjani, 2012). In 2018, the number of Senior High School students in Samarinda was 869, which was dominated by four major ethnic groups, i.e., Javanese, Bugis, Kutai, and Banjar about $36.13 \%, 10.12 \%, 10.12 \%$, and $14.84 \%$, respectively. While other ethnicities are $27.68 \%$, consists of other ethnic groups, both local and migrant ethnic groups (Boleng \& Maasawet, 2018).

Based on the diversity of ethnicities in Samarinda and the potential of several SAbMs in optimizing the biology learning process on the topic of "Cells and tissue organisms' 'bodies", it is necessary to conduct research that examines the effect of these two conditions on students' critical thinking skills. This study has a clear distinction from previous studies because most of the previous studies only examined the effect of SAbM on learning outcomes (Hsu, Yen, \& Lai, 2016; Panasan \& Nuangchalerm, 2010) or thinking skills (Ersoy \& Baser, 2014; Hussin, Harun, \& Shukor, 2018), while other studies only examined the effect of ethnicity on students' belief (Rubie-Davies et al., 2012) and learning participation (Ke \& Kwak, 2013). Furthermore, previous studies have only examined the effect of PBL (Kuvac \& Koc, 2018; Thakur \& Dutt, 2017) and GI (Saefullah et al., 2017; Vlassi \& Karaliota, 2013), while research that combines PBL and GI is still difficult to find. Therefore, the aimed of this study was to examine the effect of combining PBL and $\mathrm{Gl}$ and ethnic differences on students' critical thinking skills. This research is urgent to do because the findings of this study can be used to optimize the learning process in multiethnic conditions. In addition, an assessment of the difference in effects between $\mathrm{PBL}, \mathrm{GI}$, and $\mathrm{PBL}+\mathrm{Gl}$ integration will provide new information on whether the combination of the two SAbMs have a significant effect on 21 st Century skills empowerment or not.

\section{METHOD}

This study was a quasi-experiment, which conducted on the odd semester of the academic year of 2018/2019. Four classes were selected by purposive sampling of $11^{\text {th }}$ class (primary in mathematics and natural sciences) from 2 senior high schools in Samarinda, Indonesia. The study population was all students with ethnic backgrounds of Javanese, Bugis, Kutai, Banjar, and Toraja. The sampling criteria were at least there are three students with the background of the five ethnicities in the class. A total of 143 students involved 
in this study, divided in $P B L, G I, P B L+G I$ and Conventional classes with the number of $31,21,22$, and 32 students, respectively. While the number of students with different ethnicity background in the class implementing the PBL were 14, 4, 5, 4 and 4 for Javanese, Kutai, Toraja, Bugis, and Banjar, respectively; In the GI class were 4, 4, 4, 5 and 4 for Javanese, Kutai, Toraja, Bugis, and Banjar, respectively; In the PBL+GI class were 6, 4, 4, 4 and 4 for Javanese, Kutai, Toraja, Bugis, and Banjar, respectively; In the Conventional class were 13, 4, 6, 5 and 4 for Javanese, Kutai, Toraja, Bugis, and Banjar, respectively. The students have equality academic background as shown by National Junior High School student test score data. The ethnicity of the students was listed at the beginning of the experiment. The students were continuously participating in the learning activities (subject to their respective groups) during this study.

The experimental design of this study was the non-equivalent pre-test post-test control group design. The study group was divided into four groups. The four study groups consist of groups (classes) those applied: (1) Problem-Based Learning (PBL), (2) Guided Inquiry (GI), (3) a combination of PBL and Guided Inquiry $(P B L+G I)$, and (4) Conventional. The four groups were subjective to a pre-test, in the beginning, then followed by a post-test at the end of the intervention (Figure 1).

The independent variable was a student-centered learning model and the Conventional learning model as control. The dependent variable was the critical thinking skills with indicators of (i) the skills of analyzing, (ii) making conclusions, and (iii) predicting. The relationship model between variables is shown in Figure 1.

The instruments used in the data collection process were: (1) questionnaires, and (2) questions test. The questionnaires were used to obtain information about the ethnicity of students. Furthermore, the questions test was used to collect information about the students' critical thinking skills scores before and after the application of the treatment. The form of test questions was essay. Several questions were five items, and are expected to be answered by the students within 90 minutes.

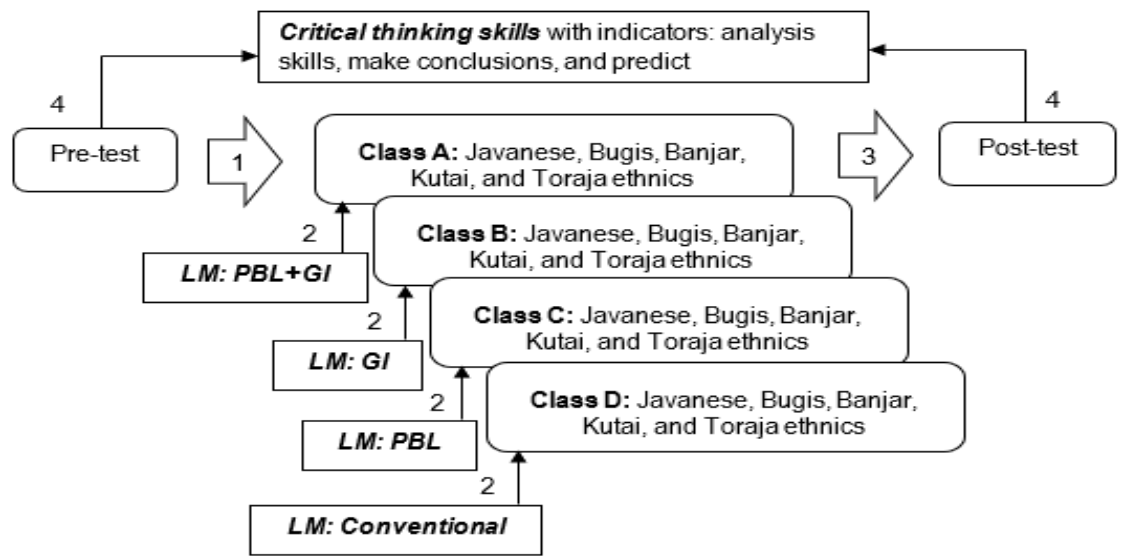

Figure 1. Model of the relationship between independent ( $L M=$ Learning Models) and dependent variables (Critical thinking skill) in the experimental design. The experiment was conducted in the rows of [1] Pre-test was applied to all class (A, B, C, and D), [2] Treatment was applied, [3] Post-test was applied, and [4] Analysis of Pre-test and Post-test result for Critical thinking skill

Table 1. Problem-Based Learning (PBL) and Guided Inquiry (GI) combined syntaxes

\begin{tabular}{lcl}
\hline \multicolumn{1}{c}{ Syntaxes } & $\circ \begin{array}{l}\text { Students observe/observe in groups the description of problems related to cells, body } \\
\text { tissues of organisms. }\end{array}$ \\
\hline Problem orientation (PBL) & $\circ \begin{array}{l}\text { Students in groups, formulate problems related to the concept of cells, organisms' body } \\
\text { tissues, after observing the problem description. }\end{array}$ \\
$\begin{array}{l}\text { Student organizations to carry } \\
\text { out studies (observations) (PBL } \\
\text { and } \mathrm{GI})\end{array}$ & $\circ \begin{array}{l}\text { Students are looking for ways to solve problems related to observation or } \\
\text { understanding the gaps contained in the problem description. }\end{array}$ \\
\hline Hypothesis (GI) & $\circ$ & Students, as a group, formulate hypotheses. \\
\hline Experiment (GI) & $\circ$ & Students in groups carry out experiments. \\
\hline Free group investigation (PBL \& GI) & $\circ$ & Students collect data needed to solve problems that have been formulated. \\
\hline $\begin{array}{l}\text { Discuss in groups related to the } \\
\text { data obtained (PBL and } \mathrm{GI})\end{array}$ & $\circ$ & $\begin{array}{l}\text { Students discuss in their groups about the data obtained to solve the problems they } \\
\text { have formulated. }\end{array}$ \\
\hline Presentation (PBL and $\mathrm{GI})$ & $\circ$ & $\begin{array}{l}\text { Students in groups present the results of their discussion to all other groups of students } \\
\text { in the class. }\end{array}$ \\
\hline
\end{tabular}

In this study, the $P B L+G I$ syntaxes are designed in seven steps (Table 1). Thus, the $P B L+G I$ become new syntax and is expected to be more empowered in improving the students' critical thinking skills. The test questions given in the pre-test and post-test are similar. The pre- and post-test results were scored using a scoring rubric, as shown in Table 2., which adapted from the rubric developed by (Hart, 1994). 
Table 2. Rubric scoring

Predictors

- There is information/data following the problems related to the organisms' cells and tissues

- Analyze following issues related to the organisms' cells and tissues

- Make logical conclusions about the organisms' cells and tissues

- Make logical predictions about the cells and tissues of the organisms' body

One of the characters below appears

- There is insufficient information/data following the problems related to the organisms' cells and tissues, or

Making analysis less relevant to the issues associated with the organisms' cells and tissues, or

Making less logical conclusions about organisms' cells and tissues, or

Make less logical predictions about the cells and tissues of the organisms' body

All characters below appear

- Lack of information/data following the problems related to the organisms' cells and tissues

Making analysis fewer following issues related to the cells and tissues of the organisms' body

Making less logical conclusions about the cells and tissues of the organisms' body

Make less logical predictions about organisms' cells and body tissues

One of the characters below appears

- There is no information/data following the problem related to the organisms' cells and tissues, or

Making analysis incompatible with issues concerning the organisms' cells and tissues, or

Make illogical conclusions about organisms' cells and tissues, or

Make unreasonable predictions about the cells and tissues of the organisms' body

The answer sheet is blank, or the answer does not match the problem

A two-way ANCOVA was conducted to examine the effects of the ethnic and learning model on critical thinking of biology subject of "cell and tissue of organisms' body" by post-test, after controlling for the pretest. A posthoc analysis by Bonferroni test was conducted. Due to the limitation to fulfill the assumptions for ANCOVA, e.g., normality and/or variance equality of the data in each group, the data were transformed into squared data before data analyzed. Only eight of twenty groups fulfill the assumptions of the two-way ANCOVA (all of learning model types and two ethnic types, i.e., Javanese and Banjar).

\section{RESULTS AND DISCUSSION}

Hundred forty-three students from the four classes were involved in this study. The PBL, GI, PBL+GI, and Conventional classes each have a number of students of $36,35,36$, and 36 , respectively. Only eight combinations from twenty groups are fulfilling the two-way ANCOVA, i.e., all the learning models types and two ethnics (Javanese and Banjar), following squared data transformation (Table 3).

Table 3. Distribution of the observed student based on learning model (class) and ethnic

\begin{tabular}{|c|c|c|c|c|}
\hline \multirow{2}{*}{ Learning model / class } & \multicolumn{2}{|c|}{ Ethnic } & \multirow{2}{*}{ Total samples ${ }^{a}$} & \multirow{2}{*}{ Total students } \\
\hline & Javanese & Banjar & & \\
\hline PBL & 14 & 4 & 31 & 36 \\
\hline $\mathrm{Gl}$ & 4 & 4 & 21 & 35 \\
\hline Conventional & 13 & 4 & 32 & 36 \\
\hline Total & 37 & 16 & 106 & 143 \\
\hline
\end{tabular}

Note: $P B L=$ Problem-Based Learning, $\mathrm{Gl}=$ Guided Inquiry. a) The number of students involved in this study (Javanese

Banjar, Bugis, Kutai, and Toraja). b) The number of students in the class.

The eight combinations showed a linear relationship between pre-test and post-intervention post-test for each intervention group, as assessed by visual inspection of a scatterplot. The homogeneity of regression slopes was also determined by a comparison between the two-way ANCOVA model with and without interaction terms, $F(7,37)=0.683, p=0.722$. The homoscedasticity within groups was proofed as assessed by visual inspection of the studentized residuals plotted against the predicted values for each group, and variances were homogeneous, as determined by Levene's test of homogeneity of variance $(p=0.448)$. There were no outliers in the data following deleted one data from the combination of the Javanese and Conventional learning model, as assessed by no cases with studentized residuals greater than \pm 3 standard deviations. There were no leverage or influential points, as evaluated by leverage values and Cook's distance, respectively. Studentized residuals were normally distributed, as assessed by ShapiroWilk's test $(p>0.05)$.

There was not a statistically significant two-way interaction between ethnic and learning models on the post-test of biology subject while controlling for pre-test, $F(3,44)=1.535, p=0.219$, partial $\eta^{2}=0.095$ (Table 
4). However, the main effect of ethnic showed no statistically significant difference in adjusted marginal mean post-test for those ethnic types, which Javanese (5070.687) versus Banjar (4885.891), 184.796 (95\% $\mathrm{Cl},-488.495$ to 858.087$), p=0.583$. However, there was a statistically significant main effect of the LM, $F(3,44)=42.098, p<0.0005$, partial $\eta^{2}=0.742$. Adjusted marginal mean post-test increased in a row of Conventional (2006.052), GI (5324.744), PBL (6107.057), and PBL+GI (6475.304). A statistically significant difference to Conventional of $3318.69(95 \% \mathrm{Cl}, 1978.65$ to $4658.73, p<0.0005)$, 4101.01 (95\% Cl, 2890.2 to $5311.29, p<0.0005)$, and $4469.25(95 \% \mathrm{Cl}, 3197.86$ to $5740.65, p<0.0005)$ for $\mathrm{Gl}, \mathrm{PBL}$ and $\mathrm{PBL}+\mathrm{Gl}$, respectively. The pairwise comparison between learning models in each ethnic type was shown in Table 5 , and the trend of the effect was shown in Figure 2.

Table 4. Two-way ANCOVA table

\begin{tabular}{lrrrrrc}
\hline \multicolumn{1}{r}{ Source } & Type III Sum of Squares & df & Mean Square & \multicolumn{1}{c}{} & \multicolumn{1}{c}{$\boldsymbol{p}$} & Partial $\boldsymbol{\eta}^{2}$ \\
\hline Pre-test & $2,761,047.749$ & 1 & $2,761,047.749$ & 2.443 & 0.125 & 0.053 \\
Ethnic & $345,874.401$ & 1 & $345,874.401$ & 0.306 & 0.583 & 0.007 \\
SAbM & $142,760,697.856$ & 3 & $47,586,899.285$ & 42.098 & 0.000 & 0.742 \\
Ethnic * SAbM & $5,206,843.918$ & 3 & $1,735,614.639$ & 1.535 & 0.219 & 0.095 \\
Error & $49,737,277.641$ & 44 & $1,130,392.674$ & & & \\
\hline
\end{tabular}

Dependent Variable: Squared Post-test; a. $R 2=0.787$ (R2adj=0.749); LM=Learning Model

Table 5. Pairwise comparisons of effect between learning model in each ethnic

\begin{tabular}{|c|c|c|c|c|c|c|c|}
\hline \multirow{2}{*}{ Ethnic } & \multirow{2}{*}{$\begin{array}{l}\text { (I) Learning } \\
\text { Model }\end{array}$} & \multirow{2}{*}{$\begin{array}{l}\text { (J) Learning } \\
\text { Model }\end{array}$} & \multirow{2}{*}{$\begin{array}{c}\text { Mean } \\
\text { Difference (I-J) }\end{array}$} & \multirow{2}{*}{ Std. Error } & \multirow{2}{*}{ Sig. ${ }^{b}$} & \multicolumn{2}{|c|}{$95 \% \mathrm{Cl}^{b}$} \\
\hline & & & & & & Lower Bound & Upper Bound \\
\hline \multirow[t]{5}{*}{ Java } & Conventional & $\overline{\mathrm{PBL}}$ & $-3300.403^{*}$ & 423.155 & 0.000 & -4469.502 & -2131.305 \\
\hline & & $\mathrm{Gl}$ & $-3355.598^{*}$ & 609.842 & 0.000 & -5040.479 & -1670.716 \\
\hline & & $\mathrm{PBL}+\mathrm{GI}$ & $-4279.375^{*}$ & 533.785 & 0.000 & -5754.123 & -2804.626 \\
\hline & PBL & $\mathrm{Gl}$ & -55.194 & 622.423 & 1.000 & -1774.834 & 1664.445 \\
\hline & & $\mathrm{PBL}+\mathrm{GI}$ & -978.971 & 518.862 & 0.395 & -2412.491 & 454.548 \\
\hline \multirow[t]{5}{*}{ Banjar } & Conventional & PBL & $-4901.608^{*}$ & 756.005 & 0.000 & -6990.311 & -2812.906 \\
\hline & & $\mathrm{Gl}$ & $-3281.787^{*}$ & 752.417 & 0.000 & -5360.576 & -1202.999 \\
\hline & & $\mathrm{PBL}+\mathrm{GI}$ & $-4659.129^{*}$ & 751.990 & 0.000 & -6736.739 & -2581.520 \\
\hline & PBL & $\mathrm{Gl}$ & 1619.821 & 759.836 & 0.232 & -479.466 & 3719.108 \\
\hline & & $\mathrm{PBL}+\mathrm{GI}$ & 242.479 & 758.000 & 1.000 & -1851.736 & 2336.694 \\
\hline
\end{tabular}

Dependent Variable: Squared Post-test, Covariates (Squared Pre-test) = 379.7736; Based on estimated marginal means; *) The mean difference is significant at the 0.05 level; b) Adjustment for multiple comparisons: Bonferroni.

Through implementing SAbM, students are facilitate to develop their thoughts and ideas and work together with friends to solve a problem (Nurhasanah, Arasti, Susanti, Rumperiai, \& Hindun, 2020; Wormack et al., 2019). A learning environment that enables the empowerment of critical thinking skills allows students to apply critical thinking skills (Petchtone \& Sumalee, 2014). However, students from various ethnic groups have a unique learning experience after implementing the syntaxes of the learning models applied. Therefore, the results of this study inform that, although not significant, there were differences in critical thinking skills' test achievement of students who have different ethnic backgrounds.

The achievement of students' critical thinking skills in each learning model requires the collaboration of students of different ethnic backgrounds. Their ethnic background determines the character of students. Ethnic students who vary in the class also raises the character of students. Teachers, educators, and policymakers have to design together on exciting activities in learning, including learning materials, syllabi, and learning methods that are suitable for fostering positive attitudes of students (Aladdin, 2010; Batarchuk, 2017).

Indicators of students' critical thinking skills, such as analytical skills, conclusion skills, and predictive skills, can be owned by students if, in the learning process, students conduct scientific studies. The learning models allows students to formulate problems, conduct data collection (investigation), analyze data, discuss the results of data analysis, and conclude; enable students to develop analytical skills, conclude based on analysis and discussion, and predict based on the data they have related to cells and tissues of the organisms' body subject. Data collection activities in learning, and literacy activities enable students to explore scientific cases (Odegaard, Haug, Mork, \& Sorvik, 2015), in which guide students in carrying out scientific activities logically by the guidance of trained teachers (Sarigoz, 2012). Therefore, biology teachers are expected to prefer and apply learning models whose syntax allows students to carry out activities scientifically to empower their critical thinking skills.

Furthermore, the ethnicity of students does not affect students' critical thinking skills (Table 5). The results of the data analysis show that the five types of ethnicities of students (Javanese, Bugis, Kutai, Banjar, and 
Toraja), statistically did not have a different effect in empowering students' critical thinking skills. Students in overseas areas, such as in the city of Samarinda, who was born and grew up and mature in the city of Samarinda, tended to interact with students with different ethnic backgrounds continuously. The theory has affected modern social psychology only in the last decade or so, focusing on the effect of cross-ethnic interaction. The theory has the vision on the possibility of positive outcomes from ethnic relations if the surrounding gave suitable support (Zainal, Abu, \& Mohamad, 2010), heterogeneous cultures and identities exist within these distinct groups (Jamil, 2010), but integration does not require the loss of one's identity or origins (Ruthner, 2012).

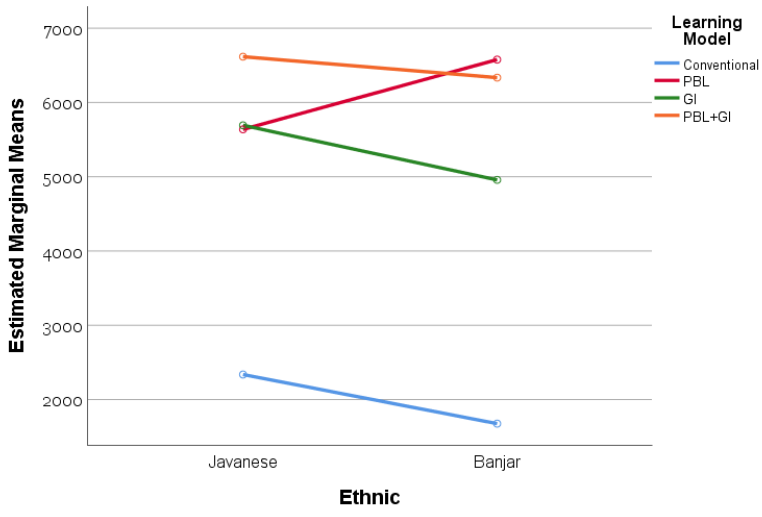

(a)

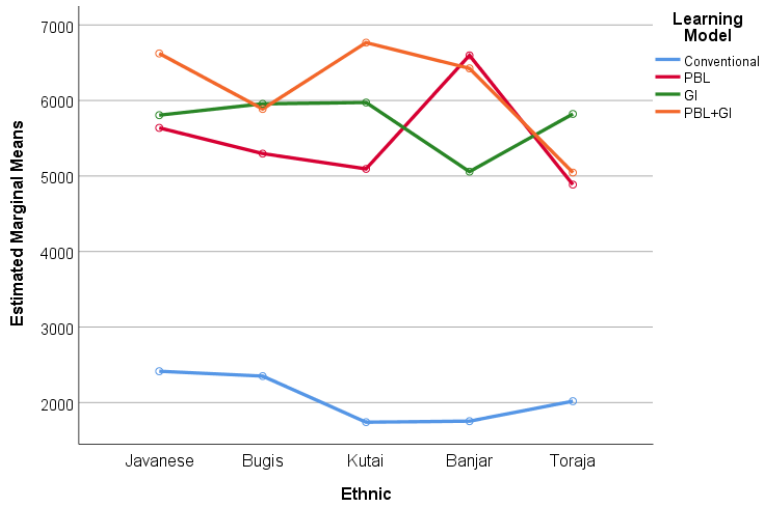

(c)

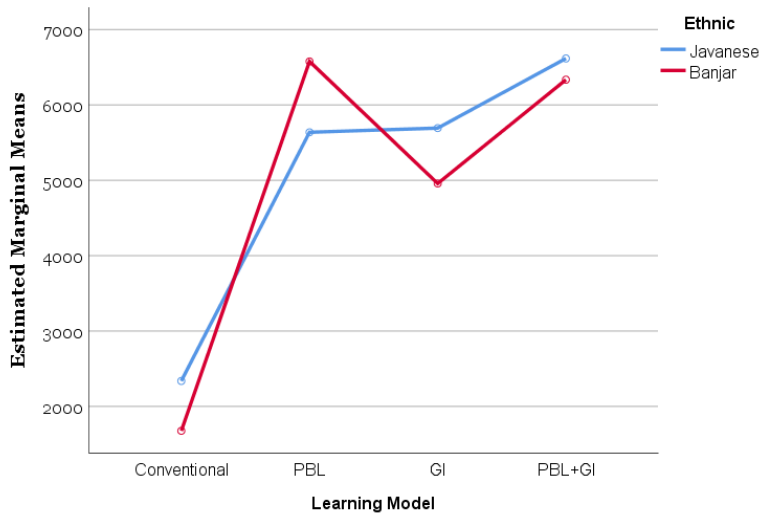

(b)

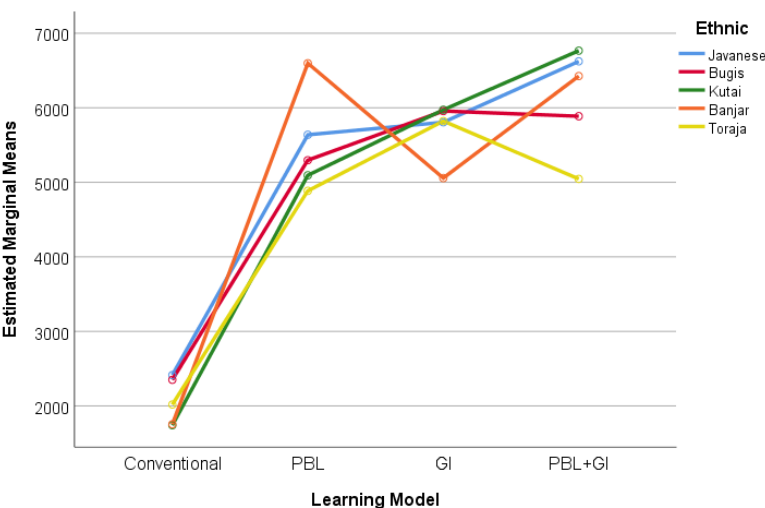

(d)

Figure 2. The trend of effect between the learning model in each ethnic. Data (squared post-test) fulfilled all of the two-way ANCOVA assumption ( $a$ and b) with the covariate (pre-test) of 379.7736, while ( $c$ and d) were from all data collected in this study with the covariate (pre-test) of 430.7264 .

The sample size factors for each ethnicity included in the study were not the same. An optimal sample size should be carefully evaluated and determined (Wang, Xu, Li, Tian, \& Chen, 2019). Therefore, it is recommended for similar research in the future to increase the sample size for each ethnic student. Besides, the size of the number of students in each ethnic group is not too much different.

Students who have a particular ethnicity tend to have unique characters that are different from students with different ethnicities. Student character gives influence to students in acting, including in following the learning process in class. For generations, unique characters from certain ethnic groups are taught and passed on by parents to their children. Bugis ethnic characteristics in general are: sipakatau (the nature of respect as individuals with dignity), siri (self-esteem, shame), pesse (brotherhood of fellow Bugis ethnicity, and with other ethnicities) (Syarif, Sumarmi, \& Astina, 2016). Javanese ethnic character, in general, is: maintaining harmony and respect (Idrus, 2012). The Banjar ethnic character is of a high religious nature (Hidayat, 2013). The Toraja ethnic character is always learning about the Toraja ethnic culture, namely: Toraja language, Toraja exceptional food, and Toraja special food (Bahfiarti, 2015). The ethnic character of Kutai is to always live according to the teachings of Islam for its adherents, and the kinship system, in general, is patrilineal (fatherly line) and has a religious system and customs that are held in high esteem (Murjani, 2012). However, the interaction between students with different ethnicities may also affect the student character. 
The average score of critical thinking skills for each learning model is different (Table 6). However, overall, the application of SAbM (PBL, GI, and PBL+GI combination), gives the same score, and is equally higher than conventional learning. The inquiry experiment improved the participants' critical thinking skills (Zhou, Guo, Liu, Wang, \& Ma, 2010). Besides, the application of the combined PBL+GI provides the highest score among other learning models in empowering critical thinking skills of students of varying ethnicity. Learning models that are based on a scientific approach enable students to develop critical thinking skills (indicators: analysis, inferring, and predicting). Students experience more experience in analyzing problems/data, concluding, and predicting data-based on the cells and tissues of organisms' subject.

Table 6. The empowerment of critical thinking skills in the biology object of "Cells and Tissue organisms' body"

\begin{tabular}{llccc}
\hline Ethnics & Learning Model (N) & Post-test Mean & SD & Empowerment (\%) \\
\hline Javanese & Conventional (13) & 45.77 & 14.09 & - \\
& PBL (14) & 75.54 & 6.52 & 65.04 \\
& GI (4) & 74.38 & 5.91 & 62.50 \\
& PBL+GI (6) & 81.58 & 8.09 & 78.25 \\
\hline Banjar & Conventional (4) & 39.00 & 11.17 & - \\
& PBL (4) & 81.25 & 7.22 & 77.52 \\
& GI (4) & 69.50 & 4.93 & 51.85 \\
& PBL+GI (4) & 78.75 & 7.77 & 72.06 \\
\hline
\end{tabular}

Note: $N=$ number of students. Covariates (pre-test) was 18.48 .

The application of $P B L+G I$ for Javanese, gives the highest score of critical thinking skills (81.58) compared to other learning models (Table 6). In the application of combined $P B L+G I$, students have gained more experience in analyzing problems/data, concluding, and predicting data-based about cells and body tissues of organisms' subject. Students can learn how to formulate apparent research problems. Furthermore, students can also learn to choose ways to collect data, analyze data, and discuss the results of data analysis obtained. Finally, students can make conclusions to determine accepted or rejected hypotheses that they have formulated. Javanese character is cooperation, always compact with people who are not Javanese in one group of collaboration, respect, a sense of equality with people who are not Javanese or others (Susetyo, Widiyatmadi, \& Sudiantara, 2014). Usually, Javanese succeed in interacting with other ethnic groups, have an attitude of tolerance, are patient in facing problems (Idrus, 2012).

Related to the application of learning models in the Banjar ethnic group, Table 6 shows that PBL gives the highest critical thinking skills score (81.25) compared to other learning models. Application of the PBL, students observe the real (contextual) data, formulate problems, collect data, analyze data, discuss the results of data analysis earnestly to solve the problem, and make conclusions. The character of Banjar ethnic (a local ethnic in East Kalimantan Province, who migrated from South Kalimantan Province, Indonesia), is always in contact with God, the concept of bubuhan (which helps one another), being severe in working in solving problems in his life (Istiqomah, 2014).

Conventional learning only makes it possible to practice listening, taking notes, and asking the teacher. Students are less trained to interact with their peers to analyze equally, formulate problems, formulate hypotheses, collect data, analyze data, discuss the results of data analysis, and make conclusions. As a result, students are weak in analyzing, making conclusions, and predicting. Therefore, biology teachers need to reduce the application of conventional learning, to empower students' critical thinking skills further. However, it has been realized that a preservice teachers' ability is essential to be developed in parallel to increase the teachers' capacity in practicing the science-approach learning models (Zhou et al., 2010).

Application of the scientific approach-based learning model significantly empowers $(p=0.0005)$ the critical thinking skill of the students on the biology object of "Cell and tissue organisms' body" (Table 5). Base on the ANCOVA result (Table 5), the empowering effectiveness is shown more directly using the raw data, as shown in Table 6. The PBL was more effective than $\mathrm{GI}$ and $\mathrm{PBL}+\mathrm{Gl}$ in empowering the critical thinking skill of Banjar ethnic students, while the PBL+GI was more effective for Javanese students. The GI shows the lowest effectiveness than the two other learning models for the two ethnicities.

The results of the analysis of the empowerment of learning models applied in the study (Table 6) indicate that learning models based on scientific approach (PBL, GI, and $P B L+G I)$ provide higher critical thinking skills scores compared to conventional learning. The learning process is based on a scientific approach, allowing students to experience stages of scientific assessment. The scientific assessment stages include: formulating the problem, formulating hypotheses, collecting data, discussing the data obtained, making conclusions, and sharing the findings with other students in the class. The stages of learning like this allow students to be able to do analysis, make conclusions, and can make predictions based on data obtained. 
Through a scientific approach, students are more active, and not only learn in the classroom, but also make observations in their environment in collecting data following problems in learning. In this such condition, students can find the fact that there is a relationship between the object being analyzed with learning material (Susilo, 2016). This approach avoids verbalism concept in the learning activity, has a principle of the learning process for the students from 'be informed' to 'actively find out'. In discussing the material of cells and tissues of the organism's body, students are expected not to be passive in receiving information in class. Still, it is also necessary to make observations in the laboratory and find information from other sources. Cells and body tissues of the organism are microscopic. Therefore, to study this material, it is necessary to observe this object using another microscope for assistive devices, which could reduce misconceptions in understanding the substance of cells and body tissues of organisms.

\section{CONCLUSION}

Based on the results, there is no interaction between learning models and ethnic groups on critical thinking of the biological subject as shown by the main effect of ethnicity. However, the SAbM (PBL, GI, PBL+GI) implementation significantly affects students' critical thinking skills among various ethnic students. Within Javanese, $\mathrm{PBL}+\mathrm{Gl}$ is the most powerful in empowering critical thinking, while within Banjar ethnic, the PBL was the most effective.

Based on the conclusions obtained, the application of SAbM needs to be applied massively. The number of schools that still apply conventional learning in Samarinda needs to be followed up because they are unable to optimize the empowerment of students' thinking skills. Therefore, it is hoped that researchers and policy makers will be able to encourage teachers to consistently implement various SAbM, especially $P B L+G I$.

\section{ACKNOWLEDGMENT}

We thank the Rector of University of Mulawarman, Indonesia, for funding support for the study, with Decree Number 1965/SK/2019, dated: August 30th 2019.

\section{REFERENCES}

Ahmad, Y., \& Yusof, N. M. (2010). Ethnic boundary among students in Malaysian primary schools and social interaction: A conceptual framework. In Procedia - Social and Behavioral Sciences (Vol. 7, pp. 82-91). doi: https://doi.org/10.1016/j.sbspro.2010.10.013

Aladdin, A. (2010). Non-Muslim Malaysian Learners of Arabic (NMMLAs): An investigation of their attitudes and motivation towards learning Arabic as a foreign language in multiethnic and multicultural Malaysia. In Procedia - Social and Behavioral Sciences (Vol. 9, pp. 1805-1811). doi: https://doi.org/10.1016/j.sbspro.2010.12.404

Andersen, A. L., Brunoe, T. D., \& Nielsen, K. (2019). Engineering education in changeable and reconfigurable manufacturing: Using problem-based learning in a learning factory environment. In Procedia CIRP (Vol. 81, pp. 7-12). Elsevier. doi: https://doi.org/10.1016/j.procir.2019.03.002

Arslan, A. (2014). Transition between open and guided inquiry instruction. Procedia - Social and Behavioral Sciences, 141, 407-412. doi: https://doi.org/10.1016/j.sbspro.2014.05.071

Bahfiarti, T. (2015). Cultivation cultural values Toraja parents and children through family communication in Makassar city. KRITIS : Jurnal IImu Sosial dan IImu Politik Universitas Hasanuddin, 1(2), 209-218. Retrieved from http://journal.unhas.ac.id/index.php/kritis/article/view/15

Batarchuk, D. S. (2017). The problem of interethnic youth relations in multiethnic educational environment. In Procedia - Social and Behavioral Sciences (Vol. 237, pp. 1589-1592). Elsevier. doi: https://doi.org/10.1016/j.sbspro.2017.07.001

Boleng, D. T., Lumowa, S., Palenewen, E., \& Corebima, A. D. (2017). The effect of learning models on biology critical thinking skills of multiethnic students at senior high schools In Indonesia. Problem of Education in the 21st Century, 75(2), 136-143. Retrieved from http://www.scientiasocialis.It/pec/node/files/pdf/vol75/136-143.Boleng_Vol.75-2_PEC.pdf

Boleng, D. T., \& Maasawet, E. T. (2018). The effectiveness of problem-based learning on biology concept gaining of senior High school multiethnic students in Samarinda, Indonesia. Advances in Intelligent Systems Research, 224, 94-98. doi: https://doi.org/10.2991/esic-18.2019.22 
Çimer, A. (2012). What makes biology learning difficult and effective: Students' views. Educational Research and Reviews, 7(3), 61-71. doi: https://doi.org/10.5897/ERR11.205

Crowley, Ú. (2015). Review of critical thinking skills. AISHE, 7(3), 2641-2645. Retrieved from http://ojs.aishe.org/index.php/aishe-j/article/download/264/361

Dring, J. C. (2019). Problem-based learning - Experiencing and understanding the prominence during medical school: Perspective. Annals of Medicine and Surgery, 47, 27-28. doi: https://doi.org/10.1016/j.amsu.2019.09.004

Ersoy, E., \& Baser, N. e. (2014). The effects of problem-based learning method in higher education on creative thinking. Procedia - Social and Behavioral Sciences, 116, 3494-3498. doi: https://doi.org/10.1016/j.sbspro.2014.01.790

Etobro, A. B., \& Fabinu, O. E. (2017). Students' perceptions of difficult concepts in Biology in senior secondary schools in Lagos State. Global Journal of Educational Research, 16, 139-147. doi: https://doi.org/10.4314/gjedr.v16i2.8

Firman, F., Baedhowi, B., \& Murtini, W. (2018). The effectiveness of the scientific approach to improve student learning outcomes. International Journal of Active Learning, 3(2), 86-91. Retrieved from https://journal.unnes.ac.id/nju/index.php/ijal/article/view/13003

Hart, D. (1994). Authentic assessment: A handbook fo educator. California: Addison-Wesley Publishing Company. Retrieved from https://eric.ed.gov/?id=ED447179

Hidayat, Y. (2013). Social relationship between Banjar ethnic and Madura etthnic in Banjarmasin city. Komunitas: International Journal of Indonesian Society and Culture, 5(1), 87-92. doi: https://doi.org/10.15294/komunitas.v5i1.2377

Hsu, C., Yen, S., \& Lai, W. (2016). The effect of problem-based learning on learning outcomes of accounting students. Asian Journal of Finance \& Accounting, 8(2), 135-154. doi: https://doi.org/10.5296/ajfa.v8i2.9917

Hussin, W. N. T. W., Harun, J., \& Shukor, N. A. (2018). Problem based learning to enhance students critical thinking skill via online tools. Asian Social Science, 15(1), 14-23. doi: https://doi.org/10.5539/ass.v15n1p14

Idrus, M. (2012). Character education at Javanese family. Jurnal Pendidikan Karakter, 2(2), 118-130. doi: https://doi.org/10.21831/jpk.v0i2.1297

Istiqomah, E. (2014). Culture value of Banjar society South Kalimantan: Indigenous study. Jurnal Psikologi Teori dan Terapan, 5(1), 2087-1708. doi: https://doi.org/10.1017/CBO9781107415324.004

Jamil, H. (2010). The aspiration for educational rights in educational policies for national integration in Malaysian pluralistic society. In Procedia - Social and Behavioral Sciences (Vol. 9, pp. 158-173). doi: https://doi.org/10.1016/j.sbspro.2010.12.130

Jayapalan, A., Wong, L. P., \& Aghamohammadi, N. (2018). A qualitative study to explore understanding and perception of sexual abuse among undergraduate students of different ethnicities. Women's Studies International Forum, 69, 26-32. doi: https://doi.org/10.1016/j.wsif.2018.04.004

Ke, F., \& Kwak, D. (2013). Online learning across ethnicity and age: A study on learning interaction participation, perception, and learning satisfaction. Computers \& Education, 61, 43-51. doi: https://doi.org/10.1016/j.compedu.2012.09.003

Kuvac, M., \& Koc, I. (2018). The effect of problem-based learning on the environmental attitudes of preservice science teachers. Educational Studies, 45(1), 1-23. doi: https://doi.org/10.1080/03055698.2018.1443795

Murjani, M. (2012). Interaction of religion and politic law of Kutai Kartanegara Empire: Ethnic religious study of Dayak-Kutai ethnic. Mazahib: Jurnal Pemikiran Hukum Islam, 10(1), 15-26. Retrieved from https://journal.iain-samarinda.ac.id/index.php/mazahib/article/view/106/83

Nurhasanah, S., Arasti, A., Susanti, F. D., Rumperiai, M. G., \& Hindun, I. (2020). Pengembangan instrumen penilaian kemampuan berpikir kritis siswa SMA pada pembelajaran CBL. In Prosiding Seminar Nasional V 2019: Peran Pendidikan dalam Konservasi dan Pengelolaan Lingkungan Berkelanjutan (pp. 347353). Retrieved from http://research-report.umm.ac.id/index.php/psnpb/article/view/3613/3576

Odegaard, M., Haug, B., Mork, S., \& Sorvik, G. O. (2015). Budding science and literacy. A classroom video study of the challenges and support in an integrated inquiry and literacy teaching model. In Procedia Social and Behavioral Sciences (Vol. 167, pp. 274-278). Elsevier B.V. doi: https://doi.org/10.1016/j.sbspro.2014.12.674

Panasan, M., \& Nuangchalerm, P. (2010). Learning outcomes of project-based and inquiry-based learning 
activities. Journal of Social Sciences, 6(2), 252-255. Retrieved from https://files.eric.ed.gov/fulltext/ED509723.pdf

Panlumlers, K., \& Wannapiroon, P. (2015). Design of cooperative problem-based learning activities to enhance cooperation Skill in online environment. In Procedia - Social and Behavioral Sciences (Vol. 174, pp. 2184-2190). Elsevier. doi: https://doi.org/10.1016/j.sbspro.2015.02.019

Petchtone, P., \& Sumalee, C. (2014). The validation of web-based learning environment model to enhance cognitive skills and critical thinking for undergraduate students. In Procedia - Social and Behavioral Sciences (Vol. 116, pp. 669-673). Elsevier B.V. doi: https://doi.org/10.1016/j.sbspro.2014.01.277

Rubie-Davies, C., Peterson, E., Garrett, L., Watson, P., Flint, A., O’Neill, H., \& Donald, L. M. (2012). Ethnicity as a factor in student beliefs. In Procedia - Social and Behavioral Sciences (Vol. 69, pp. 262-270). doi: https://doi.org/10.1016/j.sbspro.2012.11.408

Ruthner, A. R. (2012). The status of the German minority within the multi-ethnic educational system of the banat region - a Historical overview focusing on the multicultural character of the region. In Procedia Social and Behavioral Sciences (Vol. 46, pp. 1435-1439). doi: https://doi.org/10.1016/j.sbspro.2012.05.316

Saefullah, A., Samanhudi, U., Nulhakim, L., Berlian, L., Rakhmawan, A., Rohimah, B., \& El Islami, R. A. Z. (2017). Efforts to improve scientific literacy of students through guided inquiry learning based on local wisdom of Baduy's society. Jurnal Penelitian dan Pembelajaran IPA, 3(2), 84-91. doi: https://doi.org/10.30870/jppi.v3i2.2482

Sarigoz, O. (2012). Assessment of the high school students' critical thinking skills. In Procedia - Social and Behavioral Sciences (Vol. 46, pp. 5315-5319). doi: https://doi.org/10.1016/j.sbspro.2012.06.430

Servant-Miklos, V. F. C. (2019). Fifty years on: A retrospective on the world's first problem-based learning Programme at McMaster University Medical School. Health Professions Education, 5(1), 3-12. doi: https://doi.org/10.1016/j.hpe.2018.04.002

Susetyo, D. B., Widiyatmadi, H. E., \& Sudiantara, Y. (2014). Self concept self appreciation of Javanese people. Psikodimensia, 13(1), 47. doi: https://doi.org/10.24167/psiko.v13i1.277

Susilo, M. J. (2016). Scientific approach-based learning in Biology at Junior High School Muhammadiyah 2 Depok Sleman. In Proceeding Biology Education Conference (Vol. 13, pp. 97-101). Retrieved from https://jurnal.uns.ac.id/prosbi/article/view/5666

Syarif, E., Sumarmi, S., \& Astina, I. K. (2016). Integration of cultural value of Bugis Makassar ethnic in learning process as one of facing strategy on Asean Economic Community. Jurnal Teori dan Praksis Pembelajaran IPS, 1(1), 13-21. doi: https://doi.org/10.17977/um022v1i12016p013

Thakur, P., \& Dutt, S. (2017). Problem based learning in biology: Its effect on achievement motivation of students of 9 th standard. International Journal of Multidisciplinary Education and Research, 2(2), 99104. Retrieved from http://www.educationjournal.in/download/186/2-2-53-447.pdf

Tyabaev, A. E., Sedelnikova, S. F., \& Voytovich, A. V. (2015). Student-centered learning: The experience of teaching international students in Russian universities. In Procedia - Social and Behavioral Sciences (Vol. 215, pp. 84-89). Elsevier B.V. doi: https://doi.org/10.1016/j.sbspro.2015.11.578

Vlassi, M., \& Karaliota, A. (2013). The comparison between guided inquiry and traditional teaching method. A case study for the teaching of the structure of matter to 8th grade Greek students. In Procedia - Social and Behavioral Sciences (Vol. 93, pp. 494-497). Elsevier. doi: https://doi.org/10.1016/j.sbspro.2013.09.226

Wang, J., Xu, L., Li, B., Tian, S., \& Chen, Y. (2019). An evaluation of the effects of sample size on estimating length composition of catches from tuna longline fisheries using computer simulations. Aquaculture and Fisheries, 5(3), 122-130. doi: https://doi.org/10.1016/j.aaf.2019.09.001

Wormack, L., Brechtel, L., Ubah, C., Frazier, A., Jackson, C. G., \& Nathaniel, T. I. (2019). A student-centered intervention program to educate and retain knowledge in stroke education and healthy habits. Preventive Medicine Reports, 14, 100878. doi: https://doi.org/10.1016/j.pmedr.2019.100878

Zainal, K., Abu, D. T., \& Mohamad, Z. (2010). The effect of ethnic relations course on the students perceptions towards ethnic relations among first year students of one public university in Malaysia. In Procedia - Social and Behavioral Sciences (Vol. 2, pp. 3596-3599). Elsevier. doi: https://doi.org/10.1016/j.sbspro.2010.03.558

Zhou, Q., Guo, J., Liu, Y., Wang, T., \& Ma, J. (2010). Promoting preservice teacher's critical thinking disposition by inquiry-based chemical experiment. In Procedia - Social and Behavioral Sciences (Vol. 9, pp. 1429-1436). doi: https://doi.org/10.1016/j.sbspro.2010.12.345 